\title{
EDUCATION, SKILL TRAINING, AND LIFELONG LEARNING IN THE ERA OF TECHNOLOGICAL REVOLUTION
}

Jinyoung Kim and Cyn-Young Park

NO. 606

January 2020
ADB ECONOMICS
WORKING PAPER SERIES

$\mathrm{ADB}$ 


\section{ADB Economics Working Paper Series}

\section{Education, Skill Training, and Lifelong Learning in the Era of Technological Revolution}

Jinyoung Kim and Cyn-Young Park

No. 606 | January 2020
Jinyoung Kim (jinykim@korea.ac.kr) is a professor of Economics at Korea University. Cyn-Young Park (cypark@adb.org) is a director of the Regional Cooperation and Integration Division in the Economic Research and Regional Cooperation Department of the Asian Development Bank.

This paper was prepared as background material for the Asian Economic Integration Report 2019/2020 on "Demographic Change, Productivity, and the Role of Technology."

We express our appreciation to Seono Yoon and Racquel Claveria for their excellent research assistance. We also thank Aiko Kikkawa Takenaka for her helpful comments. 
(C) 2020 Asian Development Bank 6 ADB Avenue, Mandaluyong City, 1550 Metro Manila, Philippines

Tel +632 8632 4444; Fax +63286362444

www.adb.org

Some rights reserved. Published in 2020.

ISSN 2313-6537 (print), 2313-6545 (electronic)

Publication Stock No. WPS200008-2

DOI: http://dx.doi.org/10.22617/WPS200008-2

The views expressed in this publication are those of the authors and do not necessarily reflect the views and policies of the Asian Development Bank (ADB) or its Board of Governors or the governments they represent.

ADB does not guarantee the accuracy of the data included in this publication and accepts no responsibility for any consequence of their use. The mention of specific companies or products of manufacturers does not imply that they are endorsed or recommended by ADB in preference to others of a similar nature that are not mentioned.

By making any designation of or reference to a particular territory or geographic area, or by using the term "country" in this document, $A D B$ does not intend to make any judgments as to the legal or other status of any territory or area.

This work is available under the Creative Commons Attribution 3.0 IGO license (CC BY 3.0 IGO)

https://creativecommons.org/licenses/by/3.0/igo/. By using the content of this publication, you agree to be bound by the terms of this license. For attribution, translations, adaptations, and permissions, please read the provisions and terms of use at https://www.adb.org/terms-use\#openaccess.

This CC license does not apply to non-ADB copyright materials in this publication. If the material is attributed to another source, please contact the copyright owner or publisher of that source for permission to reproduce it. $\mathrm{ADB}$ cannot be held liable for any claims that arise as a result of your use of the material.

Please contact pubsmarketing@adb.org if you have questions or comments with respect to content, or if you wish to obtain copyright permission for your intended use that does not fall within these terms, or for permission to use the ADB logo.

Corrigenda to ADB publications may be found at http://www.adb.org/publications/corrigenda.

Notes:

In this publication, "\$” refers to United States dollars.

ADB recognizes "Korea" as the Republic of Korea.

The ADB Economics Working Paper Series presents data, information, and/or findings from ongoing research and studies to encourage exchange of ideas and to elicit comment and feedback about development issues in Asia and the Pacific. Since papers in this series are intended for quick and easy dissemination, the content may or may not be fully edited and may later be modified for final publication. 


\section{CONTENTS}

FIGURES

ABSTRACT V v

$\begin{array}{ll}\text { I. INTRODUCTION } & 1\end{array}$

II. HUMAN CAPITAL AND LIFELONG LEARNING 2

III. RECENT FINDINGS ON HUMAN CAPITAL AND SKILL FORMATION 6

A. $\quad$ Declining Productivity for Old Workers with New Technology 6

B. Job Polarization in the Era of New Technologies 8

C. Effectiveness of Job Training Programs 9

D. Effect of Early Childhood Education 10

E. Findings from Field Experiments 11

IV. POLICY RECOMMENDATIONS BASED ON THE RECENT FINDINGS

A. $\quad$ Early Childhood Learning 11

B. Quality of Formal Education $\quad 12$

C. Job Training 13

D. Enhance the Role of Local Governments 13

E. Information and Communications Technology in E-Learning 13

V. CONCLUDING REMARKS

$\begin{array}{ll}\text { REFERENCES } & 15\end{array}$ 


\section{FIGURES}

1 Average Years of Schooling in Asia and the Pacific, 1960 and 2010

$2 \quad$ Life Expectancy in Asia and the Pacific, 1960 and 2017

3 Growth of Employment by Skill Level in the United States

$4 \quad$ Productivity by Age at Individual Level (Psychometric Tests)

5 Top 1\% Income Shares across the World, 1920-2016 


\begin{abstract}
Rapid technological development makes skills depreciate faster than in the past while new technologies generate gaps in workers' skills and call for the acquisition of proper skills and lifelong learning. Proper skill mixes for future jobs include strong cognitive skills, basic information and communication technology, and analytical skills, as well as a range of noncognitive skills such as creativity, problem-solving, critical thinking, and communication. Retraining and reskilling workers is also crucial. All these changes lead to a major rethinking of education and skill training throughout a person's life. This paper reviews the recent studies on human capital and skill formation in the era of rapid technological progress. Findings from these studies particularly in labor economics can shed light on new directions for lifelong education policies.
\end{abstract}

Keywords: education policy, lifelong learning, population aging, technology

JEL codes: I25, I28, J00, J24, O15, O33 


\section{INTRODUCTION}

Recent rapid development of new technologies opens up new opportunities for both businesses and workers. However, the readiness to adopt and implement new technologies varies significantly across economies, industries, and enterprises. Such readiness can be assessed by economic infrastructure (including digital infrastructure, mobile and internet connectivity, network and data centers, and data platforms) and business operations (including digital processes, digital payments, and customer and supply chain interactions). But as technologies transform work and the workplace, workforce readiness for these changes would be the most crucial factor for success.

Workers are already experiencing the significant changes of technological progress and its impact on work and the workplace. As technology rapidly advances, workers' skills depreciate in tandem and this imposes a need for proper skill management on the workforce. Work and the workplace will start to appear dramatically different from now on. This is expected to be a formidable policy challenge, particularly as workers are expected to have longer careers amid rising life expectancy.

Greater interaction between humans and machines enabled by new technologies will raise labor productivity but require different and often higher skills, new technology interfaces, different wage models in some cases, and different types of investments by businesses and workers to acquire skills.

Empirical studies have shown that new technologies are also generating gaps in skills and earnings and thus raising inequality among the population (Juhn, Murphy, and Pierce 1993). Gaps may arise as new technologies increase demand for workers with high skills in complex jobs while reducing demand for low-level skills and routine jobs. Rapid technological progress can thus worsen inequality by making some jobs obsolete.

Worker readiness for technology adoption and digital jobs varies significantly. Higher-income countries typically have higher skill levels, and their labor forces thus have greater capacity for utilizing advancing technologies; conversely, developing parts of the world are significantly handicapped for absorbing new technologies. ${ }^{1}$

It thus becomes imperative for workers to acquire the skills that meet their evolving job requirements and to maintain and update these skills over their lifetime. Proper skill mixes for future jobs would include strong cognitive skills such as literacy and numeracy, basic information technology, analytical skills, and noncognitive skills ranging from creativity, through problem-solving and critical thinking. Other increasingly important skills include interpersonal and communication skills and emotional skills such as self-awareness and the ability to manage stress and adapt to changes.

All these changes lead to a major rethinking of education and skill training. First of all, we should acknowledge the necessity for lifelong learning of workers. Formal education can no longer be the major focus for policy makers to improve worker productivity. Instead, workers and governments must recognize the importance of learning and acquiring skills throughout a worker's life.

\footnotetext{
The World Economic Forum's Human Capital Capacity Index is one measure of a country's skill level (WEF 2017). It measures the percentage of the workforce that has attained tertiary, secondary, and primary education, as well as the percentage that has literacy and numeracy skills.
} 
What kind of lifelong learning policies should be adopted in this era of rapid technological progress? In this report, we gather recent findings from theoretical and empirical studies in labor economics, especially in the education economics literature, that deals with the effects of education policies and systems in order to reveal new directions for policies in this area based on the recent studies and findings. Based on these findings, we suggest new directions for lifelong learning policies to help people accumulate and maintain skills and prepare them for future work. Without effective policies, the gap between skill and nonskill workers will aggravate the trend of income inequality, leading to social instability and undermining inclusive growth efforts.

\section{HUMAN CAPITAL AND LIFELONG LEARNING}

One of the key developments in modern labor economics since the second half of the last century is human capital theory. Pioneered by Schultz (1961), Becker (1993) and Mincer (1974), the theory argues that skills or knowledge are the most crucial determinants of a worker's labor productivity and therefore a key factor in wages and earnings. Schultz (1961) argued that both knowledge and skill should be considered as a form of capital, which is a product of "deliberate investment." He then reasoned how an increase in investment in human capital would lead to an overall increase in productivity and workers' earnings. Becker (1993) employed the theory to account for the distribution of income among workers, while Mincer (1974) empirically investigated the evolution of labor earnings over a worker's career.

In the above studies and the related work that followed, close attention was paid to the contribution of schooling, or years of formal schooling, to earnings or labor productivity. ${ }^{2}$ This is not surprising, in that the expansion of formal education in developing and developed countries was still rapid at that time and educational achievement within and across countries varied considerably.

Governments around the world prioritized the implementation of effective policies for improving educational systems, with a keen interest in formal education such as primary through tertiary schools as a vehicle for knowledge or skill acquisition.

In recent years, as noted, this has shifted toward lifelong skill acquisition as new technologies have emerged. A few changes in the structure and environment of the economy in recent decades can account for this shift.

First, the expansion of formal education at the external margin (that is, years of schooling) even among many developing economies in Asia has reached or rapidly approached the level in developed economies, which shifted our attention to the quality of education. Figure 1 illustrates the trend of schooling years among selected Asian economies. For example, the average years of schooling in Indonesia rose from 1.1 in 1960 to 7.3 in 2010 and from 1.6 to 7.5 in the People's Republic of China during that period.

2 For example, the so-called Mincerian regression model estimates the returns to schooling years. Since the early 1990 s, empirical research on economic growth and development have conducted cross-country regressions with schooling year data. 
Figure 1: Average Years of Schooling in Asia and the Pacific, 1960 and 2010

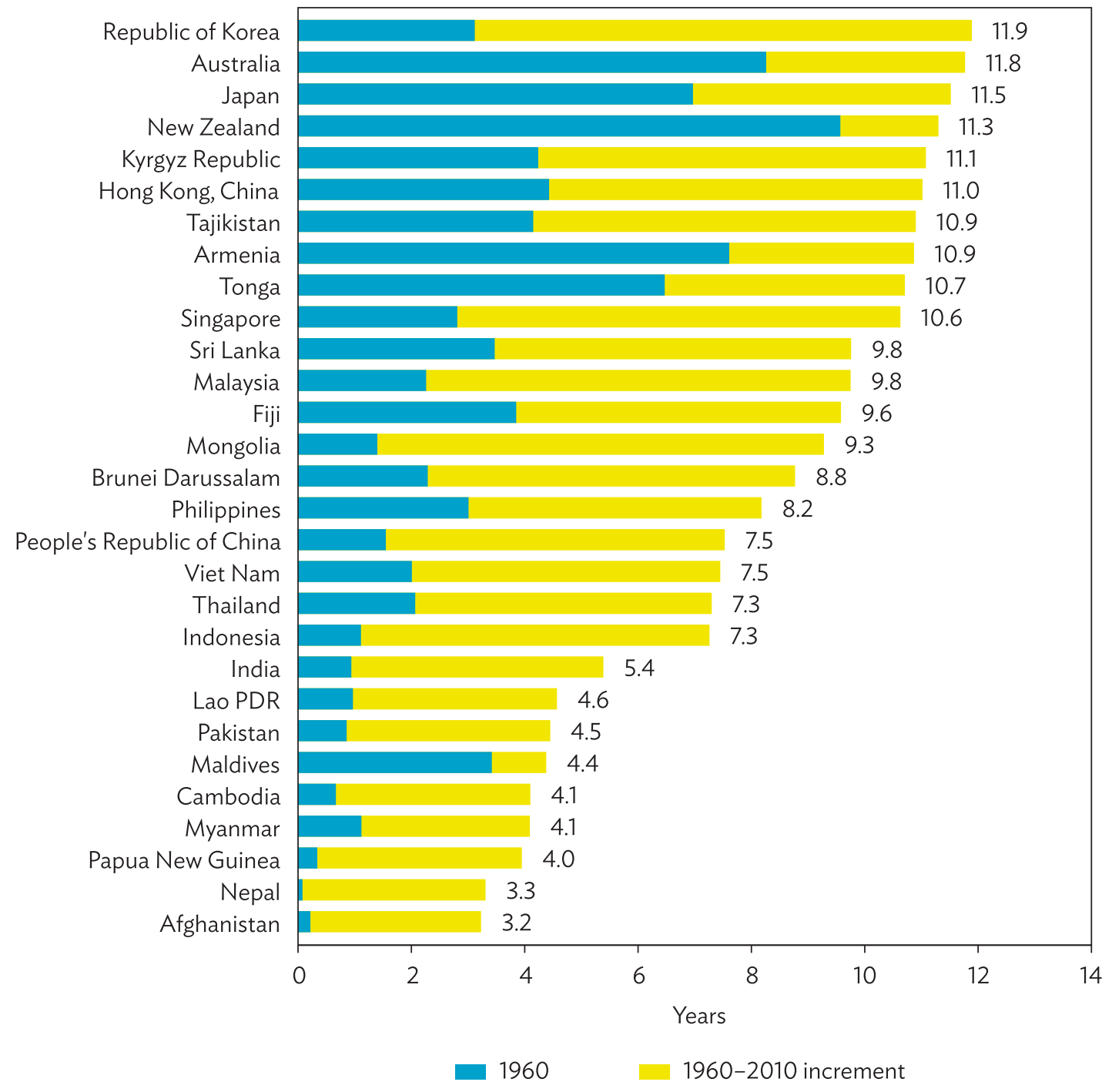

Lao PDR = Lao People's Democratic Republic.

Note: Data labels refer to average completed years of education of the population 25 and older in 2010.

Source: Barro-Lee Educational Attainment Dataset. http://www.barrolee.com/ (accessed August 2019).

Second, advancing technology has greatly affected the labor productivity of workers, especially in information and communication technology (ICT). The literature on labor productivity has shown that the age-productivity profile which describes the relationship between a typical worker's age with his or her productivity usually takes an inverted- $U$ shape, with the productivity peaking at certain ages. The rise and fall of productivity can be explained by more extensive accumulation of human capital in the earlier years of one's life, with more depreciation of human capital in later years (Bartel and Sicherman 1993; Lovaśz and Mariann 2013). Ilmakunnas and Maliranta (2016) show that the decline of productivity after the peak of the age-productivity profile is more pronounced in ICT firms compared to non-ICT firms. 
The third impact pertains to lifespan. Progress in medical science and the health-care industry have made it possible to improve health and thus extend life expectancy. On top of that, fertility among developed and many developing economies has declined significantly in the past few decades. Population aging is a particularly grave problem in some Asian economies such as the People's Republic of China, Japan, and the Republic of Korea (Figure 2).

Figure 2: Life Expectancy in Asia and the Pacific, 1960 and 2017

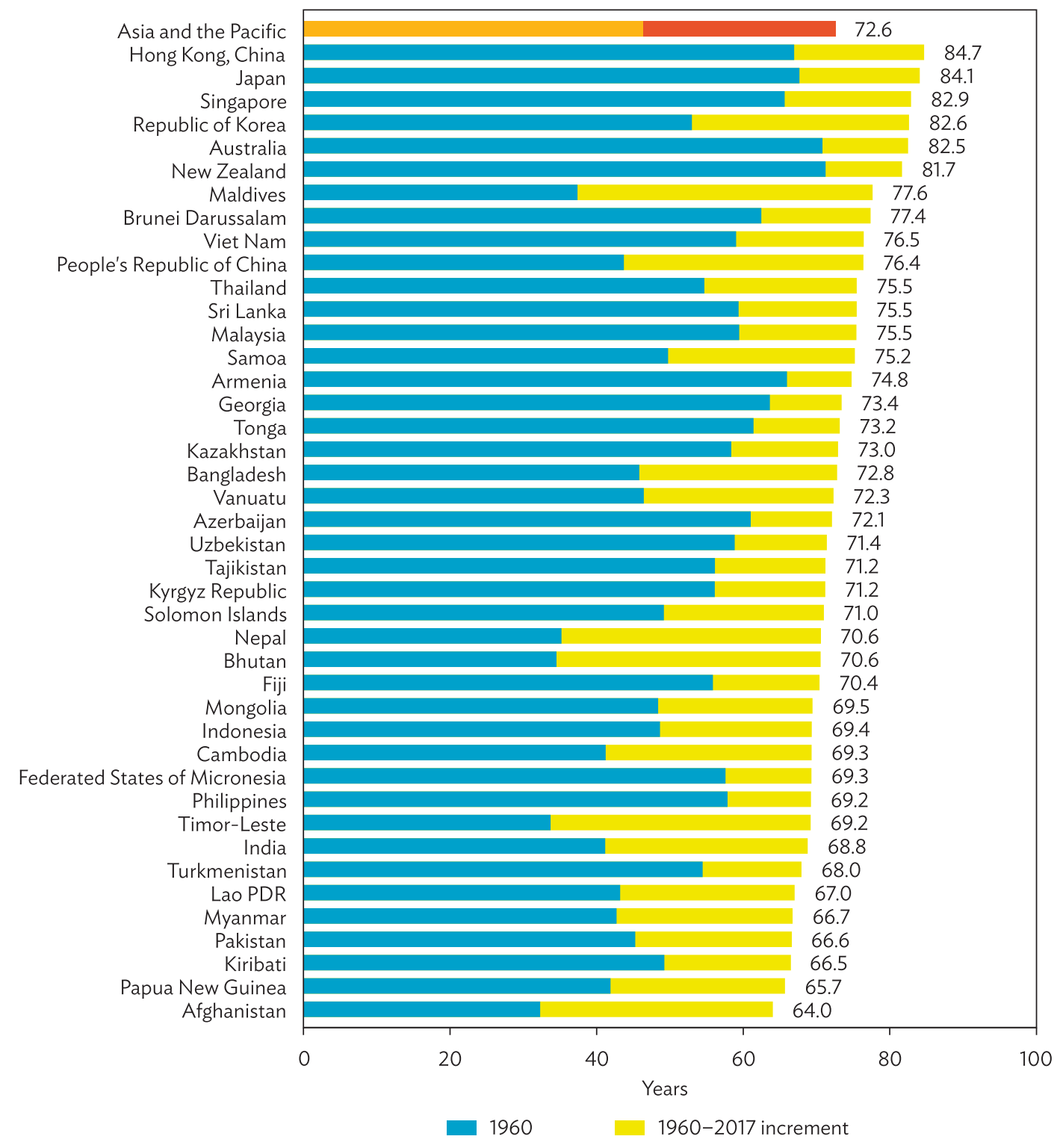

Lao PDR = Lao People's Democratic Republic.

Note: Data labels refer to life expectancy at birth in 2017.

Source: World Bank. World Development Indicators. https://data.worldbank.org/indicator/sp.dyn.le00.in (accessed July 2019). 
Finally, recent technological advancement conduces a significant change in the distribution of jobs in the labor market. Robots and automation have the potential to replace workers performing repetitive tasks, who are usually in the middle of the earnings distribution. Yet, employment in the highest and lowest paid occupations is increasing (Autor and Dorn 2013) (Figure 3). Moreover, the rise of wage inequality over the last 4 decades in industrialized economies has been accompanied by a sustained fall in real wages experienced by less educated workers (Autor 2019). We see the polarization of the labor market into good jobs and precarious jobs and the destruction of some jobs. Globalization may have also played a role in this change.

Figure 3: Growth of Employment by Skill Level in the United States

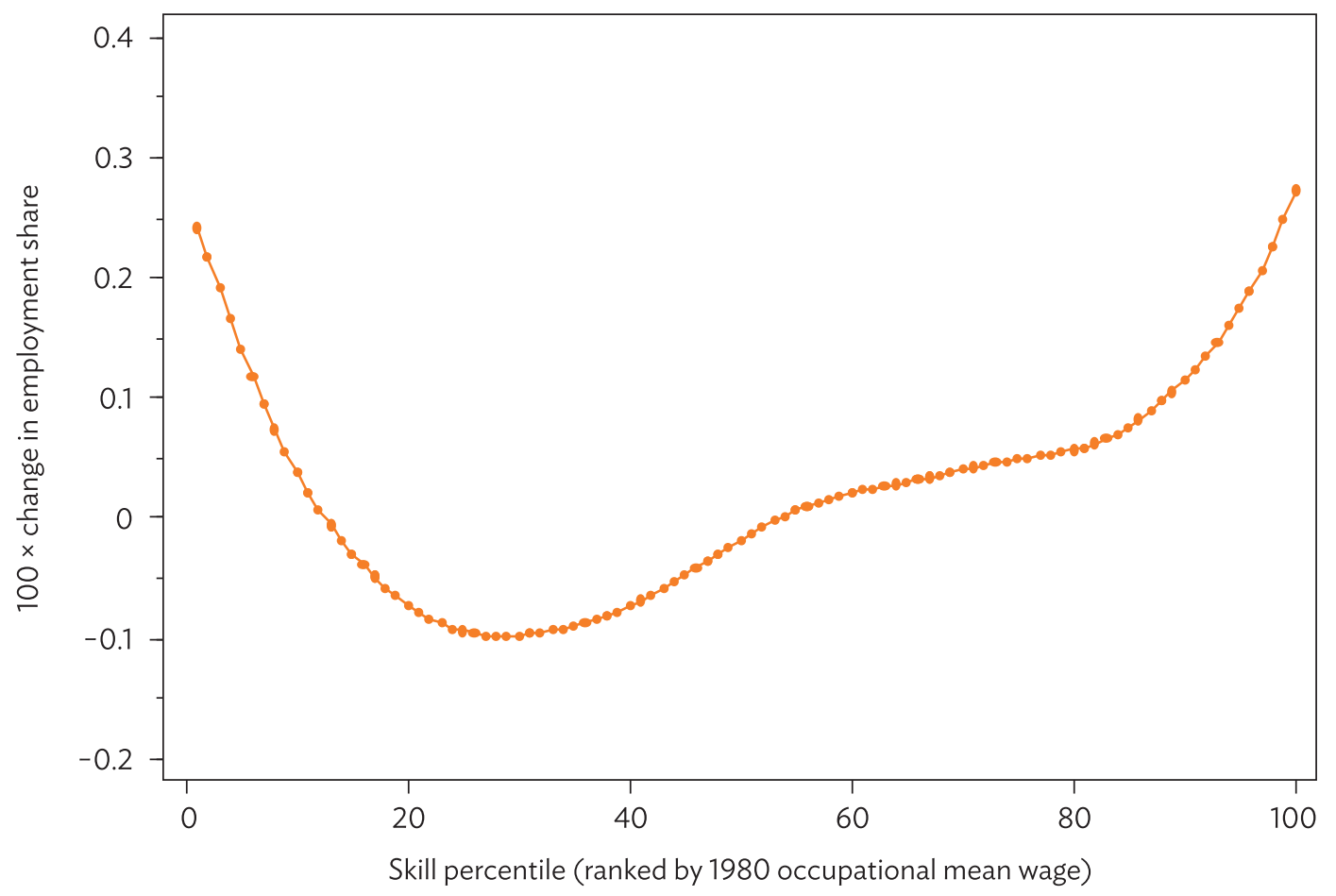

Note: This figure is constructed from Census IPUMS and American Community Survey data to calculate the change between 1980 and 2005 in the share of employment accounted for by 318 detailed occupations encompassing all of the Unites States' nonfarm employment.

Source: Autor, David H., and David Dorn. 2013. "The Growth of Low-Skill Service Jobs and the Polarization of the US Labor Market." American Economic Review 103 (5): 1553-97.

All these changes create a new situation in which people face a longer period of life with lowered productivity accompanied by a higher probability of job transition or unemployment. Naturally this new situation gets people to consider skills acquisition over the whole life cycle beyond their early, formal educations.

Governments and international institutions around the world have already recognized the urgency of establishing programs for lifelong learning. The UNESCO (1972) report, Learning to Be, addressed the idea of the totality of human life, introducing the concept of "lifelong education," 
locating formal education in the wider social context of learning throughout life. UNESCO was not the only international agency to adopt the idea of lifelong learning and promote it. It was taken up by the Council of Europe and by the Organisation for Economic Co-operation and Development (Kalen and Bengtsson 1974).

As a modern policy concept, lifelong learning was shaped in the second half of the 20th century and it is now being adapted, reinterpreted, and applied in different countries and regions. In recent years, the concept has been increasingly integrated and strengthened in national education policies through revisions and amendments. Its recognition as one of the most critical social policies began in the 1970s, and a great number of countries have since adopted various policies for promoting lifelong learning.

\section{RECENT FINDINGS ON HUMAN CAPITAL AND SKILL FORMATION}

In the past couple of decades, the economics of education has made significant progress amid the rapid advance of econometric techniques, wide availability of individual-level panel data, and above all, heightened interest in human capital and skill acquisition for workers. This section selectively lists empirical findings in the literature that can shed light on more effective policies for lifelong learning.

\section{A. Declining Productivity for Old Workers with New Technology}

A popular subject in economics and psychology has been the age effect on (or its relationship with) a person's productivity at the physical, cognitive, or economic performance level (Skirbekk [2003] provides a literature review).

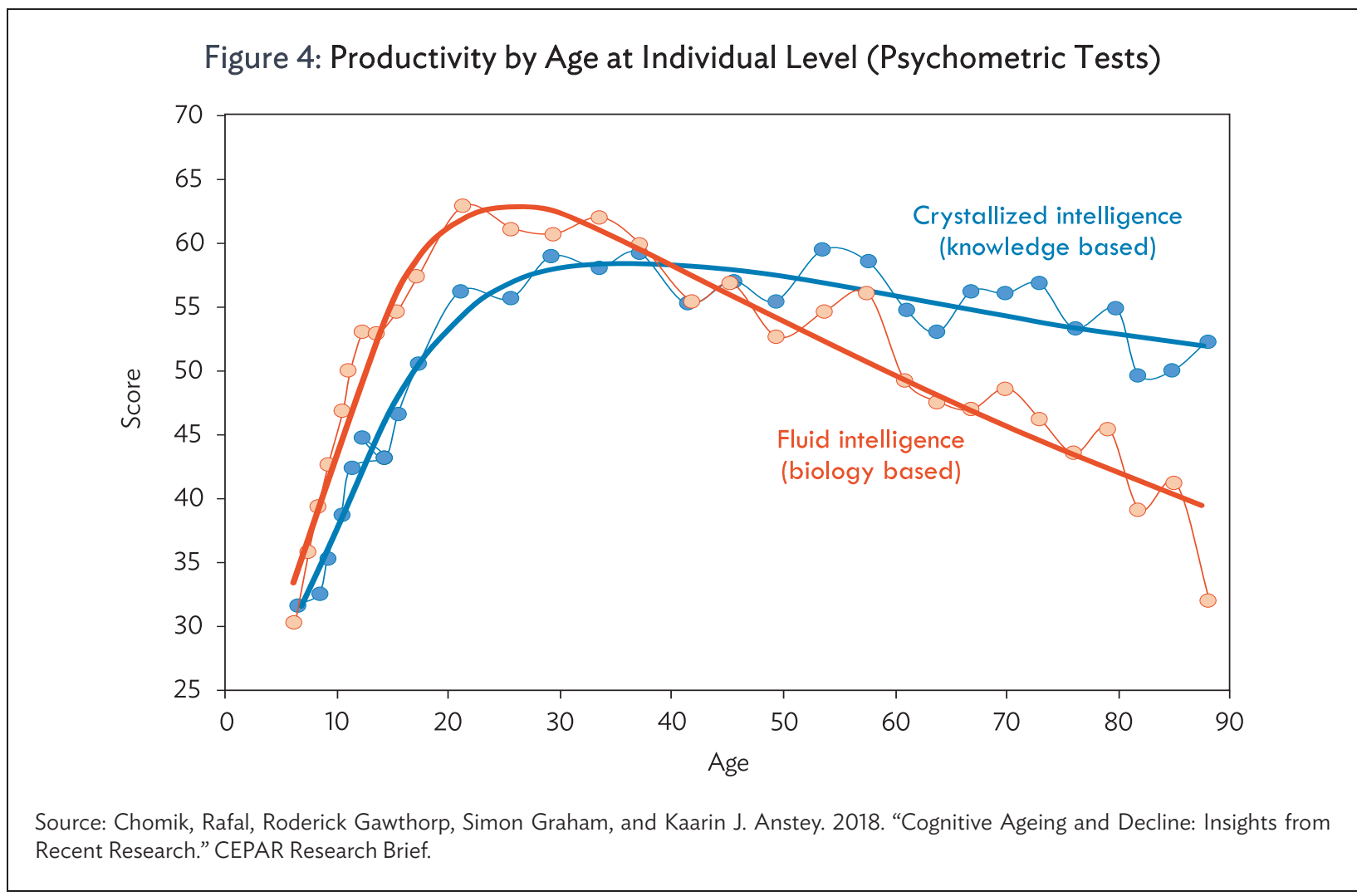


Earlier studies in economics, which used mostly cross-sectional data of workers and firms, found that the age-productivity profile takes an inverted- $U$ shape (Hellerstein, David, and Troske 1999; Skirbekk 2003; Dostie 2011). Figure 4 shows that labor productivity peaks when people are in their 20 s to 30 s. It also demonstrates that the peak differs significantly for different job skills; knowledge-based intelligence deteriorates more slowly and less over aging.

A canonical explanation in human capital theory is that a worker accumulates knowledge or skill faster than the depreciation of human capital in earlier years with the expectation of improved productivity later, but human capital depreciation becomes more prevalent as the worker ages. Yet, in industries or occupations where work experience is important for productivity, evidence suggests that the decline of human capital or productivity in old age is mild or even not present. ${ }^{3}$

Using cross-sectional data, Hellerstein, David, and Troske (1999) and Aubert and Crepon (2003) estimated simultaneously the wage equation and the production function to find the level of wage and productivity at different age groups. They found that the age-productivity profile shows a hump shape.

One concern about those studies using cross-sectional data is that there can be unobserved differences in productivity across firms. Firms may have a different distribution of workers too. Several recent studies that used panel data instead and employed the generalized estimation of moment (GMM) estimation method found that the fall of productivity in old age is not so significantly present or that the age-productivity profile is rather flat (van Ours and Stoeldraijer 2011, Göbel and Zwick 2011). However, these studies acknowledge that their results may be due to the positive selection of more productive workers who stay longer in the labor market. While using panel data, Dostie (2011) again shows a hump shape in the age-productivity profile.

As discussed in the previous section, recent studies suggest that labor productivity in old age decline faster now than in the past, as new technology skills are more likely to depreciate and become obsolete at a much faster rate than ever (Lovaśz and Mariann 2013, Ilmakunnas and Maliranta 2016). Lovaśz and Mariann (2013) suggest that modern technologies become obsolete faster than the traditional ones, leading to faster depreciation of skills. This change implies that workers need to invest more in human capital in old age or otherwise face a greater loss of income in their older years.

These studies in general indicate that the accumulation of human capital or experience can lead to rising productivity over time, but it is nonetheless checked by the depreciation of human capital with age. The age-productivity profile will eventually decline or stay flat in the later stage of a worker's career. Moreover, technology advances may accelerate a slowing in productivity for old workers. As life expectancy increases and labor productivity declines in old age, this finding also implies more poverty for old workers - an additional reason for more careful deliberation on lifelong learning policies.

3 As for wage earnings, empirical findings in earlier years usually showed that wages typically rise with age. Lazear (1979) argued that rising wages with age are due to deferred payment contracts, which provide workers an incentive not to leave their employers. 


\section{B. Job Polarization in the Era of New Technologies}

Since the mid-1980s, wage inequality has increased in the United States (US) and other developed economies after a long period of declining inequality in those economies following the end of World War I (Figure 5). Income inequality began to widen in the 1990s or later in other developing countries as well.

Figure 5: Top 1\% Income Shares across the World, 1920-2016

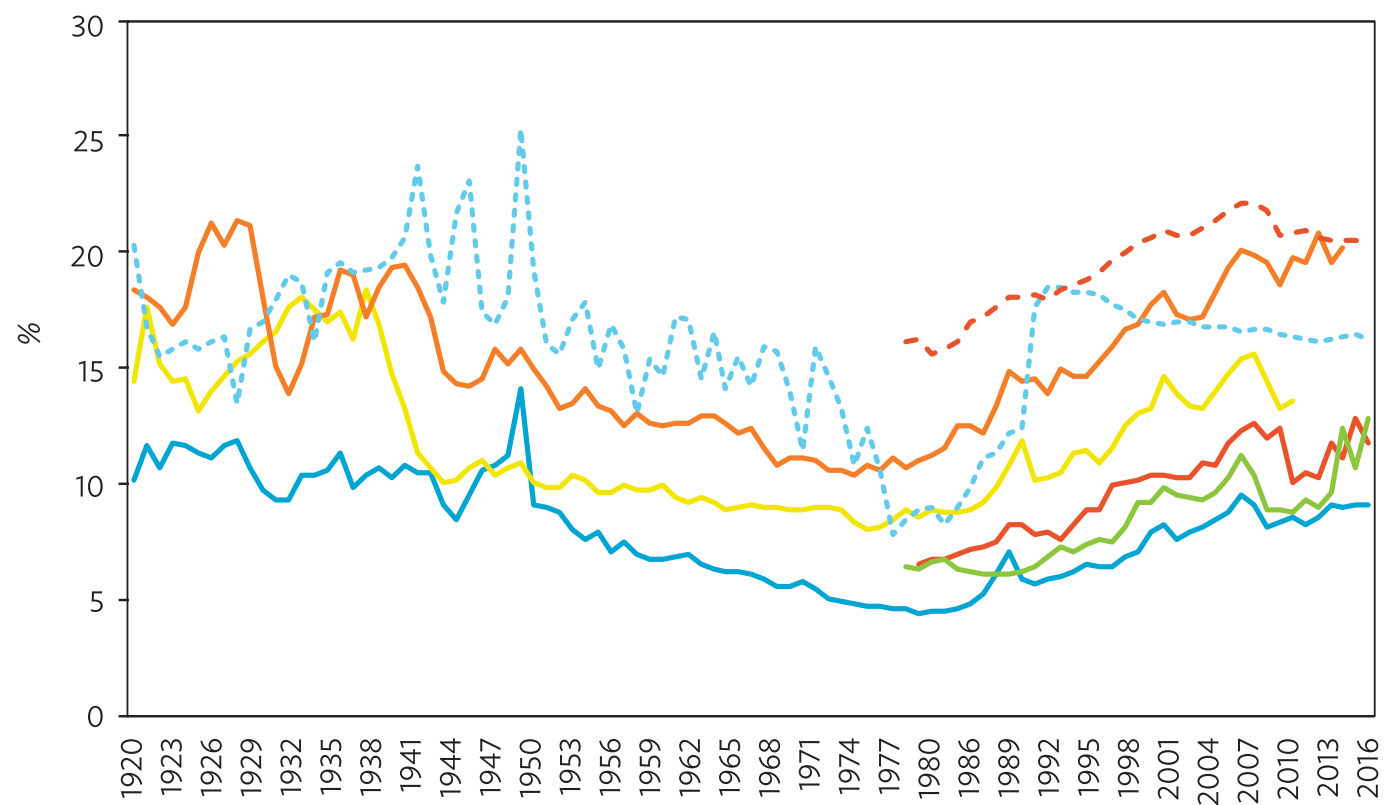

$$
\begin{aligned}
& \text { - Australia - Canada - UK - Ireland - US } \\
& \text { - World } \ldots \text { Emerging market and developing economies }
\end{aligned}
$$

UK = United Kingdom, US = United States.

Source: World Inequality Database. https://wid.world/ (accessed 22 October 2019).

Earlier studies that investigated the possible causes of this phenomenon suggested that skillbiased technical change (SBTC) in recent decades may have benefited skilled workers more than unskilled workers. SBTC implies that technological advances have boosted the productivity of skilled labor relatively more than that of unskilled labor. The development of new technologies-such as the computer and information technologies that began to make their way into workplaces in the 1970s but did not become widespread until the 1980s_increased returns from skill (Autor and Katz [1999] surveys of the SBTC hypothesis).

Autor, Levy, and Murnane (2003) argue that while the relative supply of more skilled workers has increased since the mid-1980s, the demand for skilled labor increased even more because of technological change, which increased the returns to skill. They show that information technology alone can explain between $60 \%$ and $90 \%$ of the estimated increase in relative demand for collegeeducated workers from 1970 to 1998. 
Since early 2000s, new literature emerged to recognize that skills and tasks are distinct. According to this literature, skills are applied to tasks to produce output, and skills do not directly produce output. Workers of a given skill do not always perform the same set of tasks and the assignment of skills to tasks is subject to change because changes in market prices mandate reallocation of skills to tasks or the set of tasks demanded in the economy is altered by technological developments (Autor 2013).

Acemoglu and Autor (2011) note that the recent phenomenon of job polarization (broadbased increases in employment in high- and low-skill occupations relative to middle-skilled occupations) cannot be explained by the SBTC model. Instead, they argue that the task-based model of labor demand and supply can account for the job polarization phenomenon. They claim that the evolution of technology in recent years has substituted machines for certain tasks previously performed by labor in the middle of the skill spectrum, and routine-based middle-skilled jobs are lost.

This development of job polarization indicates that there will be a significant reallocation of jobs in the coming years due to further advancement of technology, which makes job training programs more desperately needed. This development can also be age biased: it can have a more adverse impact on old workers, who typically take up routine jobs (Lewandowski et al. 2017).

\section{Effectiveness of Job Training Programs}

Governments consider public employment and training programs as well as other labor market policies as tools for absorbing the unemployed and economically disadvantaged into the labor force. And economists have intensively scrutinized public employment and training programs since the second half of the last century to investigate their effectiveness.

Based on studies of active labor market programs in the US and Europe, however, empirical evidence tends to suggest that these programs have at best a modest effect on the labor market performance of program participants after controlling for the selection problem (i.e., those more motivated and capable select themselves to enroll in training programs). Moreover, many active labor market programs and initiatives cannot pass a cost-benefit test. Even when they are cost effective, they are rarely associated with a large-scale improvement in skills (Heckman, LaLonde, and Smith 1999).

One reason for the ineffectiveness of active labor market policies is that those programs are targeted toward disadvantaged adolescents or adults who have not received adequate investment in human capital for a long time. However, new skills build on skills acquired previously and it is not easy to remedy 20 years of lacking human capital investment with a training program that lasts for a few months.

While government training programs are mostly found to be ineffective, the impact of public or private labor market programs varies widely across demographic groups. Returns to private on-the-job training (that is, in-house training within a firm) for educated workers are shown to be high, while returns to public job training for less educated workers are very low, which confirms the idea that skills beget skills (Cunha et al. 2006).

Konings and Vanormelingen (2015) estimate the impact of in-house training on worker productivity and wages in Belgium, using firm-level panel data. Their results show that when there is a 
$10 \%$ increase in the number of workers who get job training, average sales per worker, a proxy for productivity, increased from $2 \%$ to $3 \%$ after training, while wages increased from $1 \%$ to $2 \%$.

Dearden, Reed, and Van Reenen (2006), using panel data from the United Kingdom, find that in-house training is associated with a significantly improved productivity of workers. The value-added per hour increases by about $1 \%$ and hourly wages by about $1 \%$ when training increases by $1 \%$.

\section{Effect of Early Childhood Education}

One of the most significant developments in the literature of human capital and education pertains to the importance of early childhood education. Almond and Currie (2010) showed that events before 5 years old can have large long-term impacts on adult outcomes. Child and family characteristics measured at school entry do as much to explain future outcomes as factors such as years of education. Earlier studies in this literature document well that individuals vary widely in a variety of abilities, and these variations account for a substantial amount of the individual differences in socioeconomic outcomes.

More recent studies have shown that this diversity is already apparent at an early age and parental investment at home at this stage plays a powerful role in shaping these abilities (Cunha et al. 2006). When children do not receive adequate investment within families in early childhood, the consequences can be detrimental for them.

Among the abilities acquired in early childhood, recent studies have emphasized noncognitive traits such as motivation, persistence, time preference, perseverance, and self-control (as opposed to cognitive skills such as IQ) as key factors that will greatly influence educational and labor market outcomes in later years of children (Heckman 2000, Carneiro and Heckman 2003).

Cunha et al. (2006) argue that the skills acquired in early childhood augment the skills attained at later stages. For example, noncognitive skills such as self-control and emotional security may reinforce intellectual curiosity and promote more vigorous learning of cognitive skills. Skills acquired in early childhood raise the productivity of investment at subsequent stages. This renders early childhood investment very cost-effective.

An implication for government policy from these findings is that it is possible to compensate for exposure to adverse environments in early childhood if policy interventions are made sufficiently early in children's lives. The most effective way to enhance children's socioeconomic outcomes in later years and thus recoup substantial returns is to augment family resources for children from disadvantaged environments. This approach can also be an effective method for alleviating income inequality.

A recent study by García et al. (2017) estimates the life cycle benefits of various early childhood programs targeted to disadvantaged children conducted around the world. The estimated average internal rate of return is $13.7 \%$ a year and the benefit-cost ratio is estimated to be 7.3 on average. This return rate is significantly higher than returns from any other types of assets or the return rate of other government programs. 
These findings ultimately imply a need for a big shift in educational policies. Policies directed toward families and their children at early ages may more effectively improve children's school performances later on than expenditures on teacher salaries or new computers (Heckman 1999).

\section{E. Findings from Field Experiments}

Another new development in the empirical research of labor economics is the popularity of field experiments, especially in a developing country setup. The volume of this literature is already large, and it is impossible to cover all relevant studies for deriving possible implications for lifelong learning. We select a few studies that seem to be most instrumental to educational policies.

Glewwe et al. (2013) find from studies published between 1990 and 2010 that the effects of most school and teacher characteristics (including various types of public expenditures) on students' time in school and learning are statistically insignificant, especially when the evidence is limited to the "high quality" studies. A few variables that do have significant effects include availability of desks, teacher knowledge of the subjects they teach, and teacher absence. Their findings confirm the results of earlier nonexperimental studies that school resources beyond some minimum levels are not effective and what matters only is teacher quality (Angrist and Lavy 1999; Rivkin, Hanushek, and Kain 2005). Hanushek (2003) reviewed the US and international cases for the policy effectiveness of directing resources to improve the quality of the school and found that school inputs and outcomes are not systemically related. He then suggested the commonly used input policies, such as reducing class sizes or improving teacher credentials, are generally inferior to the measures that alter incentives within schools.

Duflo et al. (2015) offered evidence for the positive effects of school governance and teacher incentive on student performance. They examined a program in Kenya where randomly selected schools were funded to hire an additional teacher on an annual contract, renewable conditional on performance, and observed a significant increase in academic scores for students. When combined with a governance program that empowered parents to bring in locally hired contract teachers, the positive benefits of school reforms were strengthened.

Angrist, Bettinger, and Kremer (2006) studied the effect of Colombia's PACES program, one of the largest voucher initiatives ever implemented. The program used lotteries to distribute vouchers that partially covered the cost of private secondary school for students who maintained satisfactory academic progress. They showed that voucher winners (they were randomly selected) in that program have substantially higher high school graduation rates than losers. This finding indicates that demandside policies to give incentives to the students or trainees for education or skill acquisition can be effective, in contrast to supply-side policies such as public educational expenditure on schools.

\section{POLICY RECOMMENDATIONS BASED ON THE RECENT FINDINGS}

This section proposes policy options drawing from the recent findings in the literature of labor and educational economics, especially applicable for developing countries in Asia.

\section{A. Early Childhood Learning}

Even though advocates on lifelong learning usually emphasize learning in old age when productivity decline emerges, lifelong learning should start early in people's lives. That is because the effectiveness 
of education or human capital investment in later years of a worker's life depends critically on whether the worker is equipped with cognitive skills typically acquired in early childhood.

The estimated rate of return to early childhood education turns out to be almost twice that of common financial assets. This high return rate results from the fact that early childhood investment in human capital will complement later investment, and more skills already acquired makes further investment a lot cheaper or more efficient. From this perspective, effective policies for lifelong learning should be designed with a lifelong plan.

Early childhood education is mostly performed in a family and the role of mothers in this endeavor is well recognized. Therefore, government policies should be geared to provide appropriate environments for educating children at home. One possible area of intervention can include maternity or paternity leave and childcare leave.

Another policy area will be the public provision of childcare. A childcare facility well staffed with qualified teachers who can instill better attitudes or cognitive skills to children can be a good investment for lifelong learning.

In many developing Asian countries, women retreat from labor markets as income levels reach a certain threshold. This reflects the concept of a U-shaped relationship between female labor force participation and household income. Women tend to withdraw from the labor market as a result of an "income effect," when the household income reaches a certain threshold. Similarly, female labor force participation shows an M-shape as women withdraw from the labor market during their childbearing and childrearing periods if it is difficult or costly to find suitable childcare and household services to replace their own. Even where public childcare programs or maternity (or parental) leave is available, existing social norms may deter mothers from utilizing these. Given the complexity of women's decision to participate in the labor market, it is important to promote gender equality and equitable social norms on top of adequate provision of public childcare programs to make the public policies for early childhood education more effective.

\section{B. Quality of Formal Education}

Compulsory education is well established now in most Asian countries and school enrolment rates have improved greatly in the last few decades. Literacy rates in many of these countries have already reached high levels.

What's more important now is to raise the quality of education. One of the lessons we gleaned from the literature of education economics in the recent past is that educational expenditures should be spent wisely because supply-side policies in education such as expenditures on educational equipment are not typically effective. On the other hand, teacher quality is found to have a significant impact on children's performance.

Hiring and monitoring high-quality teachers will be essential in this regard. This can be accomplished by maintaining high standards of curriculum design and teacher performance and recognizing the significance of retraining and regularly assessing educators. 


\section{Job Training}

Government-sponsored job training before and after market participation has been an important policy area for lifelong learning. This area is becoming more important with the emergence of new technologies, such as in ICT, because the decline of productivity in later years of a worker's life is found to become swifter with faster depreciation of these skills.

However, government-sponsored job training programs are often found ineffective for improving the socioeconomic performance of trainees. The positive effect of training programs mostly arises from a positive selection of program participants: more capable people who can readily benefit from the programs are only those who participate in those job training programs.

To spread the benefit of training programs more broadly, new policies are geared toward providing job training in the private sector, which has been shown to be more effective. In-house job training in the private sector can be encouraged by government subsidies to firms for worker training.

Secondly, public policies in job training should be able to provide stronger incentive for workers to participate in job training as early as possible. More emphasis should be placed on demand-side policy for providing stronger incentives for individuals to invest more time and resources for their own skill acquisitions, instead of the supply side.

\section{Enhance the Role of Local Governments}

It is well noted that lifelong learning policies can better achieve their goals when the policies are tailored to meet the specific needs of people across age groups and regions. Efforts to address this concern have already been made in many Asian countries.

For example, Indonesia has taken steps to localize lifelong learning by participating in research on the wider benefits of joining community learning centers with support from the international community. The Indonesian government hosted a series of seminars on community education, inviting experts from the Association of Southeast Asian Nation countries to share their experiences.

More emphasis could be placed on community-based learning, because local facilities can play a vital role in creating learning environments due to their accessibility and geographic proximity to the public. People find it easier and are more motivated to utilize learning opportunities in the local learning centers in their spare time.

\section{E. Information and Communication Technology in E-Learning}

ICT has a profound impact on the growth of learning societies by making learning more accessible to a wider range of learners. This has enormous potential for building a more cohesive and robust learning society.

In particular, the role of ICT in early childhood education is rapidly evolving. Early childhood education is often used for preparing students with the basic skills they need for formal education. With increasing need to incorporate digital tools in education, digital literacy can be integrated into early childhood education to help prepare young children. ICT devices are also often used as tools for 
education to build skills in many areas, including language, drawing, motor and various cognitive skills. Studies have begun to show promising impacts of technology in these areas.

More importantly, integrating ICT in early childhood education can help narrow the digital divide for the society. Recent studies show parents in low-income families tend to be less familiar with ICT devices and applications than those in high-income families, therefore much less likely introduce ICT education programs and tools to their children. A US study finds that only about one-third of lower-income parents have downloaded educational software for their children, whereas threequarters of higher-income parents have done so (Rideout and Katz 2016).

\section{CONCLUDING REMARKS}

A wave of technological innovations is transforming the world of work. Skills are becoming obsolete quickly as technologies rapidly advance. Proper skill management of workers is also becoming ever more important as life expectancy rises. The composition of employment in the labor market is shifting toward jobs that require high-level cognitive and socio-emotional skills, while jobs with a high routine content are being automated or offshored to varying degrees.

With the fluid concept of jobs and careers in the future due to the impact of new technologies, more and more emphasis is placed on learning that continues throughout an individuals' life beyond their careers to keep up with the changes in technology and acquire flexibility in skills.

With these changes in technology and the labor market, workers as well as policy makers face daunting challenges. This paper reviews the growing literature on human capital and skill formation to suggest emerging areas of policy consideration for lifelong learning to overcome the challenge. Recent empirical findings from the labor literature in the last 2 decades are summarized to offer policy insights on early childhood education, quality of formal education, job training, the role of local community centers, and e-learning.

A caveat is in order: studies with policy implications relevant for lifelong learning are vast and continuously growing. The paper attempts to document only the relevant research that has accumulated significant evidence in the last couple of decades. The list of evidence in the paper is obviously neither exhaustive nor exclusive. 


\section{REFERENCES}

Acemoglu, Daron, and David Autor H. 2011. "Skills, Tasks and Technologies: Implications for Employment and Earnings." In Handbook of Labor Economics 4b, edited by D. Card and O. Ashenfelter, 1043-171. North Holland.

Almond, Douglas, and Janet Currie. 2010. "Human Capital before Age Five" In Handbook of Labor Economics 4B, edited by D. Card and O. Ashenfelter. North Holland.

Angrist, Joshua, Eric Bettinger, and Michael Kremer. 2006. "Long-Term Educational Consequences of Secondary School Vouchers: Evidence from Administrative Records in Colombia." American Economic Review 96 (3): 847-62.

Angrist, Joshua, and Victor Lavy. 1999. "Using Maimonides' Rule to Estimate the Effect of Class Size on Scholastic Achievement." The Quarterly Journal of Economics 114 (2): 533-75.

Aubert, Patrick, and Bruno Crépon. 2003. "Are Older Workers Less Productive? Firm-Level Evidence on Age-Productivity and Age-Wage Profiles." Economie et Statistique 368: 95-119.

Autor, David H. 2013. “The 'Task Approach' to Labor Markets: An Overview.” NBER Working Paper No. 18711.

___ 2019. "Work of the Past, Work of the Future." AEA Papers and Proceedings 109: 1-32.

Autor, David H., and David Dorn. 2013. "The Growth of Low-Skill Service Jobs and the Polarization of the US Labor Market." American Economic Review 103 (5): 1553-97.

Autor, David H., and Lawrence Katz. 1999. "Changes in the Wage Structure and Earnings Inequality." In Handbook of Labor Economics 3 (Part A), edited by D. Card and O. Ashenfelter, 1463-555. North Holland.

Autor, David H., Frank Levy, and Richard J. Murnane. 2003. "The Skill Content of Recent Technological Change: An Empirical Exploration." Quarterly Journal of Economics 118 (November): 1279-333.

Barro-Lee Educational Attainment Dataset. http://www.barrolee.com/.

Bartel, Ann P., and Nachum Sicherman. 1993. "Technological Change and Retirement.” Journal of Labor Economics 11 (1): 162-83.

Becker, Gary S. 1993. Human Capital: A Theoretical and Empirical Analysis, with Special Reference to Education (3rd ed.). Chicago: University of Chicago Press. ISBN 978-0-226-04120-9.

Carneiro, Pedro, and James J. Heckman. 2003. "Human Capital Policy." In Inequality in America: What Role for Human Capital Policies?, edited by J.J. Heckman, A.B. Krueger, and B.M. Friedman. Cambridge, MA: MIT Press.

Chomik, Rafal, Roderick Gawthorp, Simon Graham, and Kaarin J. Anstey. 2018. "Cognitive Ageing and Decline: Insights from Recent Research." CEPAR Research Brief. 
Cunha, Flavido, James J. Heckman, Lance Lochner, and Dimitriy V. Masterov. 2006. "Interpreting the Evidence on Life Cycle Skill Formation.” In Handbook of the Economics of Education, edited by E. Hanushek and F. Welch, 697-812. Amsterdam: North Holland.

Dearden, Lorraine, Howard Reed, and John Van Reenen. 2006. "The Impact of Training on Productivity and Wages: Evidence from British Panel Data." Oxford Bulletin of Economics and Statistics 68 (4): 397-421.

Dostie, Benoit. 2011. “Wages, Productivity and Aging.” De Economist 159 (2): 139-58.

Duflo, Esther, Pascaline Dupas, and Michael Kremer, 2015. "School Governance, Teacher Incentives, and Pupil-Teacher Ratios: Experimental Evidence from Kenyan Primary Schools." Journal of Public Economics 123 (C): 92-110.

García, Jorge Luis, James J. Heckman, Duncan Ermini Leaf, María José Prados. 2017. "Quantifying the Life-Cycle Benefits of a Prototypical Early Childhood Program." NBER Working Paper No. 23479.

Glewwe, Paul W., Eric A. Hanushek, Sarah D. Humpage, and Renato Ravina. 2013. "School Resources and Educational Outcomes in Developing Countries: A Review of the Literature from 1990 to 2010." Education Policy in Developing Countries, edited by Paul Glewwe, 13-64. Chicago: University of Chicago Press.

Göbel, Christian, and Thomas Zwick. 2011. "Age and Productivity: Sector Differences?” ZEW Discussion Papers No. 11-058.

Hanushek, Erik. 2003. "Failure of Input-Based Schooling Policies." The Economic Journal 113 (485): 6498. https://doi.org/10.1111/1468-0297.00099.

Heckman, James. 1999. “Doing It Right: Job Training and Education.” The Public Interest 135: 86-107.

___. 2000. "Policies to Foster Human Capital." Research in Economics 54 (1): 3-56.

Heckman, James J., Robert J. LaLonde, and Jeffrey A. Smith. 1999. "The Economics and Econometrics of Active Labor Market Programs." In Handbook of Labor Economics, edited by edited by D. Card and O. Ashenfelter, 1865-2086. North Holland.

Hellerstein, Judith K., David Neumark, and Kenneth R. Troske. 1999. "Wages, Productivity and Worker Characteristics: Evidence from Plant Level Production Function and Wage Equations." Journal of Labor Economics 17 (3): 409-46.

Ilmakunnas, Pekka, and Mika Maliranta. 2016. "How Does the Age Structure of Worker Flows Affect Firm Performance?” Journal of Productivity Analysis 46 (1): 43-62.

Juhn, Chinhui, Kevin M. Murphy, and Brooks Pierce. 1993. "Wage Inequality and the Rise in Returns to Skill.” Journal of Political Economy 101 (June): 410-42.

Kalen, Dennis, and Jarl Bengtsson. 1974. "Recurrent Education: Towards a Strategy for Lifelong Learning." Paris: OECD Publishing. 
Konings, Jozef, and Stijn Vanormelingen. 2015. "The Impact of Training on Productivity and Wages: Firm-Level Evidence.” Review of Economics and Statistics 97 (2): 485-97.

Lazear, Edward P. 1979. "Why Is there Mandatory Retirement?" Journal of Political Economy 87 (6): 1261-84.

Lewandowski, Piotr, Roma Keister, Wojciech Hardy, and Szymon Górka. 2017. "Routine and Ageing? The Intergenerational Divide in the Deroutinisation of Jobs in Europe." IZA Discussion Papers No. 10732.

Lovaśz, Anna, and Mariann Rigó. 2013. "Vintage Effects, Aging and Productivity.” Labour Economics 22: 4760.

Mincer, Jacob A. 1974. Schooling, Experience, and Earnings. Cambridge, MA: National Bureau of Economic Research.

Rideout, Victoria J., and Vikki S. Katz. 2016. "Opportunity for All? Technology and Learning in LowerIncome Families." Report of the Families and Media Project. The Joan Ganz Cooney Center at Sesame Workshop, New York.

Rivkin, Steven G., Eric A. Hanushek, and John F. Kain. 2005. "Teachers, Schools, and Academic Achievement." Econometrica 73 (2): 417-58.

Schultz, Theodore W. 1961. "Investment in Human Capital.” American Economic Review 51 (1): 1-17.

Skirbekk, Vegard. 2003. "Age and Individual Productivity: A Literature Survey." Vienna Yearbook of Population Research 2: 133-53.

United Nations Educational, Scientific and Cultural Organization (UNESCO). 1972. Learning to Be. Paris.

van Ours, Jan C., and Lenny Stoeldraijer. 2011. "Age, Wage and Productivity in Dutch Manufacturing." De Economist 159 (2): 113-37.

World Bank. World Development Indicators. https://data.worldbank.org/indicator/sp.dyn.le00.in.

World Economic Forum (WEF). 2017. The Global Human Capital Report 2017. Geneva.

World Inequality Database. https://wid.world/. 


\section{Education, Skill Training, and Lifelong Learning in the Era of Technological Revolution}

Rapid technological progress is now resulting in skills depreciation faster than it did in the past, calling for better skills management throughout workers' lifetimes. Proper skill mixes for future jobs are also different from current job requirements. This paper reviews recent studies on human capital and skill formation in the era of rapid aging and technological progress to offer policy suggestions in the field of education and lifelong learning. Findings from these studies particularly in labor and demographic economics can shed light on new directions for lifelong education policies.

\section{About the Asian Development Bank}

ADB is committed to achieving a prosperous, inclusive, resilient, and sustainable Asia and the Pacific, while sustaining its efforts to eradicate extreme poverty. Established in 1966, it is owned by 68 members -49 from the region. Its main instruments for helping its developing member countries are policy dialogue, loans, equity investments, guarantees, grants, and technical assistance. 